\title{
Causes of Infertility in Cows
}

\begin{abstract}
Alejandro Córdova Izquierdo*1, Juan Eulogio Guerra Liera², Abel Edmundo Villa Mancera ${ }^{3}$, Rubén Huerta Crispín ${ }^{3}$, Adrin Emmanuel Iglesias Reyes ${ }^{1}$, Ma de Lourdes Juárez Mosqueda ${ }^{4}$, Armando Gómez Vázquez ${ }^{5}$, Jaime Olivares Pérez ${ }^{6}$, Blanca Estela Rodriguez Denis ${ }^{7}$ and Raúl Sánchez Sánchez ${ }^{7}$
\end{abstract}

${ }^{1}$ Department of Agricultural and Animal Production, Metropolitan Autonomous University Xochimilco Unit, Mexico

${ }^{2}$ Faculty of Agronomy, Autonomous University of Sinaloa, Mexico

${ }^{3}$ Faculty of Veterinary, Benemérita Autonomous University of Puebla, Mexico

${ }^{4}$ Faculty of Veterinary Medicine, National Autonomous University of Mexico, Mexico

${ }^{5}$ Academic Division of Agricultural Sciences, Universidad Juárez Autónoma de Tabasco, Mexico

${ }^{6}$ University Academic Unit, Autonomous University of Guerrero, Mexico

${ }^{7}$ Private practice, Mexico

*Corresponding author: Alejandro Córdova Izquierdo, Department of Agricultural and Animal Production, Metropolitan Autonomous University Xochimilco Unit, Mexico.

Received Date: May 27, 2019

Published Date: June 07, 2019

\begin{abstract}
Despite the advances that exist today on feasible technologies applied in breeding and animal production, few farmers or ranchers have shown concern for improving the general environmental conditions of their Units of Animal Production, without taking into account that these conditions are largely responsible for animal health, welfare altering them and impacting significantly in the presence of problems of reproductive and productive nature, significantly increasing production costs in the dairy industry. In this paper, some nutritional causes that can cause reproductive disorders in cows are described.
\end{abstract}

Keywords: Infertility; Fertility; Reproductive disorders; Reproductive performance cows

\section{Introduction}

Most of the chronic nutritional deficiencies determine, first, a decrease in the rate of growth; In adult animals, loss of muscle status, weakness and death. Nutrition infertility can be present in cases such as: if the amount of food available is limited during the stages of growth of heifers, from weaning to puberty, at the end of gestation and during the first few days Which follow calving, when pastures or forage crops occur on lands that have insufficient amounts of minerals considered essential for reproduction. The most common minerals are: cobalt, copper, manganese, phosphorus and selenium [1].

The effect of the metabolic changes caused by the negative energy balance (BEN), caused by the energy-poor diet, provided to high producing cows, causes low fertility; Which is caused when highprotein diets are administered in relation to energy consumption.
Diets with crude protein content of 17 to $19 \%$ may cause decreased fertility; Cows fed this way have high concentrations of urea and ammonia in blood and uterine fluids, which affects the viability of sperm, oocytes and embryos [2].

Blood urea concentrations greater than $20 \mathrm{mg} / \mathrm{dl}$ are associated with low fertility. In in vitro conditions, it has been observed that concentrations equivalent to those that would have the cows consuming diets high in protein, affect the embryonic development, which is reflected in a reduction of the proportion of embryos that arrive at the state of blastocyst.

In order to supply all the nutrients to the high producing cows, it obliges to offer high energy diets based on high proportions of grains, whose effect is reflected in subclinical alterations in ruminal $\mathrm{pH}$, being associated to problems of low fertility, due to loss of 
Gestations caused by ruminal acidosis. A proposed hypothesis of the mechanism of this phenomenon is that the diet high in grain content, causes acidosis and an elevation of free endotoxins, causing release of prostaglandin F2 $\alpha$ and regression of the corpus luteum.

We can say that poor nutrition is one of the major causes of reduced fertility in cattle in tropical/ subtropical areas. Reproductive research in the postpartum period indicates that body condition estimation (CC) is a useful indicator of the energy status and reproductive performance of dairy cows [3]. The following are the most important components to be taken into account for the good nutritional and nutritional management of dairy cows.

\section{Energy}

A negative energy balance is the main source of the problem, the origin of which is low consumption of energy-rich food [4]. In addition, other postpartum reproductive disorders may occur, such as delayed ovulation, prolonged open days, and periods of infertility, which may be temporary or permanent.

\section{Vitamins}

The absence or deficiency of vitamin A and beta-carotene in the feeding and nutrition of farm domestic females results in reproductive disorders, including placental retention. Another of the vitamins involved in the problem is the $\mathrm{E}$, whose consideration is diet is fundamental, as well as vitamin C. These vitamins are natural antioxidants and their presence in nutrition is critical for the prevention of placental retention and other disorders [5].

\section{Minerals}

The presence of micronutrients, like minerals in the feeding of reproductive animals, both females and males, is of fundamental importance. Many reproductive failures, including placental retention, could be avoided by including small amounts of the following minerals in the diet: Selenium, copper, molybdenum and zinc [5-15]. The following Table 1 shows the role of some micronutrients in the reproductive performance of dairy cows and in the reproduction of animals in general (Table 1).

Table 1: Function of micronutrients in animal reproduction $[2,5]$.

\begin{tabular}{|c|c|c|}
\hline Micronutrient & Function & Consequence Deficiency \\
\hline Vitamin A & $\begin{array}{l}\text { They maintain the integrity of the reproductive tract and } \\
\text { favor the reproductive process in females and males. }\end{array}$ & $\begin{array}{l}\text { It stops puberty, both in females and males; Predisposes to } \\
\text { low rates of fertilization and embryonic mortality, as well as to } \\
\text { placental retention and in males reduces sexual desire. }\end{array}$ \\
\hline Vitamin E & It promotes and maintains reproductive life. & $\begin{array}{l}\text { It predisposes to placental retention and in males to } \\
\text { malformations and low sperm concentration in the ejaculate. }\end{array}$ \\
\hline Selenium & $\begin{array}{l}\text { It acts as cofactor of the enzymatic system glutathione } \\
\text { peroxidase, responsible for the intra and extra cellular } \\
\text { oxidation of the cell membrane of the cells that integrate the } \\
\text { reproductive tract. }\end{array}$ & $\begin{array}{l}\text { Predisposes to low fertility; Predisposition to placental } \\
\text { retention and to ovarian cysts; In males, reduces sperm } \\
\text { motility and concentration. }\end{array}$ \\
\hline Copper & $\begin{array}{l}\text { It promotes hormonal physiology and prostaglandin } \\
\text { synthesis. }\end{array}$ & $\begin{array}{l}\text { Predisposition to low fertility; Disorders in the estrous cycle, } \\
\text { embryonic and fetal death; Abortion and placental retention. }\end{array}$ \\
\hline Zinc & $\begin{array}{l}\text { It favors the function of several metabolic enzymes and } \\
\text { hormonal function in females and males. }\end{array}$ & $\begin{array}{l}\text { Predisposition to low fertility, prolificity and placental } \\
\text { retention; In males, impairs spermatogenesis and the } \\
\text { development of secondary sex organs. }\end{array}$ \\
\hline
\end{tabular}

\section{Acknowledgement}

None.

\section{Conflicts of Interest}

No conflicts of interest.

\section{References}

1. Azab MA, Badr A, Shawki G, Medeg SSA (1993) Some microelements profile in ciclie non-breding cow sydrome (repeat breeder). Assiut Veterinary Medical Journal 29(58): 245-253.

2. Butler WR (2000) Nutritional interactions with reproductive performance in dairy cattle. Anim Reprod Sci 60-61: 449-457.

3. Córdova A, Leal A, Murillo A, José Manuel, Claudia Irais (2002) Causa de infertilidad en ganado bovino. Medicina Veterinaria 19(9): 112-124.

4. Veepro H (2002) Problemas en el periodo de parto. Mexico Holstein 33(9): 9-13.

5. Smith OB, Akinbamijo OO (2000) Micronutrients and reproduction in farm animals. Anim Reprod Sci 60-61: 549-560.

6. Cavazos F (2001) Algunas Consideraciones sobre un problema viejo: Vacas repetidoras. Veterinario de Servicio Técnico, ABS Mexico.

7. Córdova Izquierdo Alejandro, Cristian Alejandro Córdova Jiménez, Mary Silvia Córdova Jiménez y Juan Eulogio Guera Liera (2008) Efecto del Insemiandor sobre el porcentaje de vacas repetidoras. Anadero 2: 72-75.
8. Correa CJ (2000) Relación Producción, Reproducción de Alto Potencial Genético.

9. Dalton JC, Nadir S, Bame JH, Noftsinger M, Nebel RL, et al. (2001) Effect of time of insemination on number of accessory sperm, fertilization rate, and embryo quality in nonlactating dairy cattle. J Dairy Sci 84(11): 2413-2418.

10. Fourichon, C, Seegers H, Malher X (2000) Effect of Disease in the Dairy Cow: Meta-Analysis. Theriogenology 53(9): 1729-1759.

11. Howard WT, Hulgens MF, Hartwg N (1998) Manejo Lechero Reproducción Animal.

12. Landau S, Braw Tal R, Kaim M, Bor A, Bruckental I (2000) Preovulatory follicular status and diet affect the insulin and glucose content of follicles in high-yielding dairy cows. Anim Reprod Sci 64(3-4): 181-197.

13. Nebel RL, Saacke RG (2001) Fertilization Rate, and Embryo Quality in Nonlactating Dairy Cattle. J Dairy Sci 84:1277-1293.

14. Studer E (1998) A veterinary perspective on of farm evaluation of nutrition and reproduction. Journal Dairy science 81(3): 872-876.

15. Peters JL, Senger PL, Rosenberg JL, O Connor (1984) Radiographic evaluation of bovine artificial inseminating technique among professional and herdsman-inseminators using .5- and .25-ml French straws. J Anim Sci 59(6): 1671-1683. 